\title{
Keskeneräisyydessä on mielensä - vai onko?
}

Esa Poikela ja Sari Poikela (2008). Tutkimustarinoita Ounaksen varrelta. Kari E. Nurmen juhlakirja. Lapin yliopistokustannus.

\begin{abstract}
A
ikuiskasvatustiede on dogmien ja oikeiden oppi-isien tiede. Meidän on oltava niin kriittisiä - kriittisyys on itseisarvo. Opiskelijatkin pitävät kriittisistä, palopuheisista opettajista. Opiskelijat haluavat myös itse olla kriittisiä. Valitettavasti aikuiskasvatustieteen kriittisyys on yleensä ulkoa tuotettua, ennalta arvattavaa ja tieteellistä vallankäyttöä. Lounastin kuutisen vuotta sitten professorikollegoideni kanssa. Mieleeni jäi toiselle professorille suunnattu mielenkiintoinen kysymys: "Mezirow on kaluttu loppuun, kenet me nostamme seuraavaksi barrikadeille?”
\end{abstract}

Tutkimustarinoita Ounaksen varrelta -teos on aikuiskasvatustieteen professori Kari E. Nurmelle omistettu juhlakirja kunnianosoituksena emeritus professorin arvon aseman saavuttamisesta. Tuon muutamalla lauseella esille omia mietteitäni ja muistojani Kariin liittyen; sen jälkeen voi siirtyä pohtimaan, kuinka kohteensa näköinen juhlakirja on - vai onko ollenkaan?

Nuorempana kollegana olen päässyt seuraamaan Kari E. Nurmen työuraa noin kolmekymmentä vuotta. Opiskelijana ollessani Karia pidettiin Helsingin yliopiston kasvatustieteen laitoksen toisinajattelijana. Eikä kait tuo leima ole hänestä myöhemminkään kadonnut, vaikka hänen tieteellinen polkunsa veikin laitoshallinnon ja vallan kabinetteihin 1990-luvulla. Ehkäpä Karin sisällöllistä asiantuntemusta ja moniottelijan roolia kuvaa lause, jonka emeritusprofessori Johannes Alikoski minulle 1980-luvulla totesi: "Se mies on kävelevä tietokirja."

Tutkimustarinoita Ounaksen varrella -teos on artikkelikirja. Artikkeleita on yhteensä 11 kappaletta. Ne eivät sisällöllisesti kohdennu mihinkään yksittäiseen näkökulmaan tai aikuiskasvatustieteen osa-alueeseen. Pikemminkin kyseessä on aikuiskasvatustieteen sekametelisoppa: henkilöstön kehittämisestä dysleksian tiedostamiseen, ystä- vyydestä matemaattiseen minään. Myös toiseudet, maahanmuuttajanaisten kansalaisuus ja tutkimusparadigmat tulevat käsitellyksi. Niinpä niin. Teos on tieteellinen moniottelija, kuten on teoksen juhlakalukin. Näköisyyttä on.

Teos on vakavahenkisesti ja rennosti toimitettu. Artikkelit on kirjoitettu tieteellisiksi artikkeleiksi. Arvolauseet ja tosiasialauseet pidetään erilleen, ajatuksen kuljettamista on jokaisessa artikkelissa helppo seurata. Ja kuitenkin koen useimmat artikkelit avauksiksi, pieniksi neulanpistoiksi jotka viestivät: "hei, tätäkin voisi tutkia, oletko mahdollisesti ajatellut asian voivan olla näinkin?” Avaavat tekstit, jotka jättävät vastaamatta tai lyömättä teesejään seinään, pakottavat miettimään, on itse prosessoitava. Jos tulkitsemme artikkelien viestivän juhlakirjan kohteesta, olisiko tässä Kari E. Nurmen ohjauksen olemus - voisiko se olla näinkin?

Esa Poikela ja Sari Poikela ovat toimittaneet teoksen. Niinpä he ovat kirjoittaneet teoksen ensimmäisen ja viimeisen luvun. Ensimmäinen luku ottaa kantaa 
kasvun ja oppimisen tutkimiseen kasvatustieteessä. He toteavat, että perinteisen kasvatustieteen tutkimuksen kohteena ei ole ollut oppiminen vaan oppimisprosessin säätely. Mielestäni tässä on vastaus siihen, miksi aikuiskasvatustiede on tieteenalana kehittymätön. Olemme sekoittaneet toiveemme tutkimuskohteen piirteiksi. Puhumme konstruktivistisesta tai humanistisesta oppimisajattelusta, samalla siirrämme ajattelutapojen piirteet jäsentämään sitä, mitä ja millä tavalla oppijan pitäisi oppia. Ja näemme vain halutun; olisiko aika luopua älyllisestä epärehellisyydestä ja tutkia todellisuutta toiveiden sijasta!

"Inhimillisen kasvun ja kehityksen tutkiminen, joka ei rajaudu vain yksilöön, vaan yltää sosiaalisiin, organisationaalisiin ja yhteiskunnallisiin ulottuvuuksiin, oikeuttaa puhumaan oppimisen tieteestä, jonka kautta voidaan ymmärtää formaaliseen kasvatukseen kuulumattomia oppimisen ilmiötä”, toteavat Poikelat (s.12). Olen samaa mieltä. Aikuiskasvatustiede edistyy nopeasti, jos kykenemme pitämään erillään oppimisen tutkimuksen oppimisprosessin säätelyn tutkimuksesta. Myös Soili Paananen ottaa oppimisen tutkimukseen artikkelissaan vastaavalla tapaa kantaa.

\section{$\mathrm{O}$} kait hieman ilkeiltäväkin. Teoksessa Poikeloiden päättävä artikkeli käsittelee ongelmaperusteista oppimista ja freireläistä pedagogiikkaa. Vaikuttaa Freire olevan yksi nouseva klassikko, jota on muodikasta siteerata. Näin Freire asettuu samaan heimoon adornojen, habermasien, horkheimerien, frommien ja marcusien kanssa. Olen ne aikoinani 1970-luvun lopulla lukenut. Ja mieleni tekee huutaa: "Hei kolle- gat - luovutaan jo noiden loppuun kaluttujen kavereiden siteeraamisesta ja koitetaan luoda jotakin uutta.” Tunkkaisuudesta olisi päästävä eteenpäin.

$\mathrm{T}$ eoksen muista artikkeleista käsittelen vain kolmea. Kaarina Määttä tekee kokeneen tutkijan rohkean ratkaisun ystävyyttä käsittelevässä artikkelissaan. Hän lähes irrottautuu aiemmista lähteistä ja kirjoittaa esseemuotoisesti pohdiskellen. Hän vertaa ystävyyttä rakkauteen. Ja yllättävä kyllä, ystävyydessä taitaa olla enemmän arvoituksia kuin rakkaudessa. Kenties rakkaus on determinoituneempi ilmiö kuin ystävyys - ja sen vuoksi ystävyyden olemassaolon arvoitus on suurempi. Entä voiko ystävyyteen oppia -kysymys on mukavan konkreettinen ja sopiva nuoren tutkijan uran alun tutkimushaasteeksi.

Tieteen moniottelijana on Kari E. Nurmi ennättänyt paneutua yrittäjyyskasvatukseenkin. Paula Kyrön mielenkiintoinen artikkeli yrittäjyyskasvatuksesta on siten paikallaan, totean entisenä yrittäjänä ja nykyisenä keinottelijana. Ilmeisesti yrittäjyyskasvatuksessa olisi erotettava yrittäjyyden substanssi, talouden, tuotannon, palvelun, myynnin, verkostojen ja oikeudellisten asioiden hallinta. Yrittäjyyskasvatuksen substanssia on jatkuvasti päivitettävä ja se on normaalia koulutuksen suunnittelua. Ilman riittäviä tietoja on yrittäjä pian entinen yrittäjä.

Kyrö kuitenkin suuntaa artikkeliaan kysymään, millainen on yrittäjäksi ryhtyvän persoonallisuus. Mitään piirreteoreettisia kuvauksia hän ei rakenna, pikemminkin painottaa vietin, tahdon ja tiedon omaleimaista kombinoitumista yrittäjäksi hakeutu- misessa. Miten vietti voisi liittyä yrittäjyyteen? Ihmiset eroavat synnynnäisesti esimerkiksi elämyshakuisuudessaan. Riskinotto liittyy elämämyshakuisuuteen. Näin yrittäjällä olisi oltava myötäsyntyisenä ominaisuutena elämyshakuisuus, joka näkyy tietoisena ja harkittuna riskinottamisena. Milloin ja miksi kasvattajalla olisi oikeus vaikuttaa ihmisen elämyshakuisuuteen? Oppiiko ihminen elämään ongelmitta suuremmassa (yrittäjyys)riskin todellisuudessa verrattuna siihen, mikä on hänellä taipumuksena?

Minne menet, henkilöstön kehittäjä -kysymystä pohtii Matti Laitinen. On hyvä, että henkilöstön kehittämisen historiaa ja nykyistä tilannetta jäsennetään. Hän luonnostelee henkilöstön kehittäjille neljä erilaista tulevaisuuden vaihtoehtoa: ovatko henkilöstön kehittäjät tiedon tuottamisen avainhenkilöitä, marginalisoituva ja katoava ammattikunta, koulutusohjelmien organisoijia vai koulutuspakettien laatijoita?

Matti Laitinen ei artikkelissaan hyökkää tulevaisuuteen. Kenties kuitenkin voitaisiin pohtia, mikä on henkilöstön kehittämistieteen keskeisin kohde. Työsuhteet ovat suhteellisen pitkäkestoisia. Kenties henkilöstön kehittämistieteen kohde on tukea ihmisten työuria. Jos ihmiset ovat organisaatioiden tärkein voimavara, miten tuo voimavara pidetään vuosikymmenestä toiseen tuottavuuden tilassa? Sitä ei kyetä tekemään pakottamalla, se vaatii syvällistä psykologista, sosiaalispsykologista ja sosiologista tietoa ja kehittynyttä käytännön silmää. Henkilöstön kehittämisen oppaat, joissa kuvataan henkilöstön kehittämisen menetelmiä, ovat tarpeellisia, 
mutta suunnattu aloittelijalle. Jokainen normaaliälyinen ihminen oppii työssä oppimalla parissa vuodessa kehittämisen keinot: benchmarkkaamaan, organisoimaan kummityöskentelyä, suunnittelemaan koulutuspäivän. Keinojen hallinta ei vaadi koulutusta. Sitä vastoin syvällinen tieteellinen tieto auttaa vastaamaan, "mikä on se todellisuus, jossa kehittäminen toteutetaan, miten kehittämisen ongelma-avaruus määritellään”. Se on henkilöstön kehittämisen strateginen taso; taktisen ja operatiivisen tason tempputaituruus ei ole ongelmana. Strategiselta tasolta löytyy myös kehittäjien ammattikunnan identiteetti, Suomen vuoksi sitä totisesti toivon.

Olen yrittänyt kirjoittaa juhlateoksen tyyliä ja kohdetta kunnioittaen. Sain teoksesta paljon ajattelemisen aiheita, ärsykkeitä ja narunpäitä kerättäväksi. Valmiita vastauksia oli vähän. Juuri sen vuoksi teos oli antoisa. Keskeneräiset asiat muistetaan paremmin kuin ratkaistut asiat, toteaa psykologinen tutkimus. Kyllä, jäljistään ja tekemisistään professorikin muistetaan.

\section{Juha Varila}

